\title{
A CLINICAL AND EXPERIMENTAL STUDY OF THE EPIPHARYNGEAL FLORA IN EPIPHARYNGITIS
}

\author{
By \\ YUZURU TANIKAWA \\ From the Department of Oto-Rhino-Laryngology, School of Medicine, \\ Tokyo Medical and Dental University. (Director: Prof. S.Horiguti)
}

The present study has been performed, in order to elucidate the relationship between inflammation of the epipharyngeal mucosa and the flora, and agents aggravating inflammation.

The results are as follows:

1) There was a parallel relation between the change of the epipharyngeal flora and clinical symptoms of epipharyngitis, especially at the time of acute exacerbation of epipharyngitis. The change of the flora on smears was divided into 6 grades.

2) The cultual characteristics of the flora were divided into 3 types according to the growing mode on the blood agar. The characteristics of the flora had close relations with clinical course of epipharyngitis.

3) The strain, especially staphylococcus aureus, whose colony frequently showed pure culture on the blood agar was considered as one of the agents aggravating epipharyngitis.

4) The experiment in rabbits revealed the staphyloccus aureus alone could cause slight epipharyngitis, but more severe inflammation caused by the bacteria was applied to the epipharynx with the powder of charcoal.

Consequently, it is thought that dust can play an important role in exacerbation of epipharyngitis.

\section{鼻咽腔炎における鼻咽腔細菌叢の臨床的 並びに実験的研究}

東京医科菌科大学耳鼻咽喉科学教室（指導：堀口申作教授）
助 手

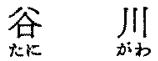
䛊変

目次

1.緒言

2. 観察対象及び方法

3. 観察結果

1 塗枺磦本

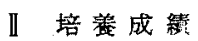

4. 小 括

5. 動物 実験

1 実験目的

I実験方法及び結果

III 小 括
6. 総括及び考按

7. 結

1. 緒

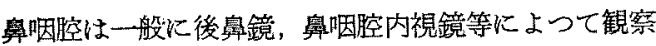
されるが，その解剖学的な関係からこの部分は比較的観 察に不便で，少くとも上記の上5な從来から行われてい る視覚的な方法によっては必ずしも常に正確な判断を下

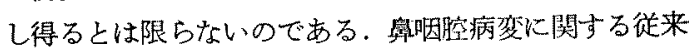
の記載が，腫煬や，咽頭扁桃の肥大等主として形態学的 に著变のあるものに限られ，鼻咽腔炎の如き，単なる発 赤の增加というような病変の記載が交湳に凡んぞみられ 
ないのはこのためであると考えられる。

しかしながら鼻咽腔炎は䠛床的には屡々，全身疾患と 繁密な関連を有し，このものの正確な観察は拯めて重大 な意義を有する。

この事から，教室においては長年に互り，各種鼻咽腔 炎の正確なる診断法の研究を行い，今日，その消長をは ほ正確に把握し得るに至つた。しかるに，兂部の細菌の 消長に関しては，それが色々な意味で重大な役割を演じ ていると考えられるに抱らず，まだ研究せられること がなかつたので，今回その研究結果を報告する次第であ る、蓋し細菌の消長が炎症の消長に密接な闑係を有する ばかりでなく，逆に炎症の消長が細菌の消長に対しても 一定の役割壳演じていると考光る事は，多くの臨床家が 観祭する所であるが，これらの間の理論的考察に関して

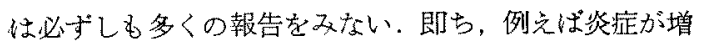
覀して細菌叢の状況が变化する場合に，これを単に細菌 の側のみからの钼祭に終始することなく，その細菌の盤 殖する母地即ち粘嗼の状態の側からるこれを考える必要 があると思执れるのである，章にも上記の如く，教宝に おいては，鼻咽腔の上皮涂抹像その他により，概部の炎 症の消長を正確に把㩧する万法を確立し得ているので， 今回，これと合せて細菌の消長を観察し，併せて雨者 の関係に関して論及する一方更に急性增悪を反覆する

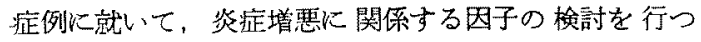
た。

次に以上の臨床成續の,中で特に炎拝增悪の因子に関す るものに就いての動物実験を行い，若干の知見を得たの で報告する次第である。

\section{2、観察対象及び方法}

钼察対象としては，鼻咽腔に炎应性所見を示さない5 名の対象及び楀咽腔炎患者71名を対象とした。 即ちこ の対象に対して隇莱した㸶頭並に茼綿棒を夫々，他の部 分に触れない上うに注意深く䁷咽腔に括入し，主として 軟口蓋舅側面の一定部位を軟く擦過し，これを戴物硝子 に登布鏡検した。

標本はその経過を追う目的から，一人の患者につき， 炎症の消長の状況に応して毎日もしくは隔日にこれを採 取した．每日少くとも二枚の標本を同時に作成し，一方 は剝離細胞学的梌索を行らために主として Papanicolou 染色を行い，剩離上皮と共に遊走細胞の観察を行い，こ れによつて㷋症の消長を観察した，別の一枚は細菌の形 態的観察を行うためにグラム染色を施した．又同時に同 し場所から採取した標本を直らに brain-heart 血液寒天
培地に㳂布， $37^{\circ} \mathrm{C} 24$ 時間培盖して観察した，発育した

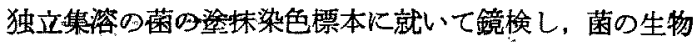
学的性状を参考としながら主として形態学的に分類同定 Lた.

このよらな標本採取は炎定性鼻咽腔を有する患者に拈 いては毎日局所の治療を行いつつ，毎日又は隔日これを 行い峏者の変化を比較観察した。

上皮細胞，遊走細胞の変化と鼻咽腔炎の消長との関係 に就いては既に教室において, 村上 ${ }^{19)}$, 紊藤 ${ }^{20)}$, 井出 22）市川 21) 等の詳細な報告があり，

1. 炎症時には線毛上皮細胞の 剝離度が著しく六進し 且つそれら細胞の種々なる形の形態的变化が，炎症の各 段階に応して観察される。

2. 炎庭時には, 赤血球，好中球等の遊出がみられ. 又慢性炎でば後舆䵇が多くなる。

3. 鼻㸶腔の塗布治療により，臨床的には炎症時に見 られた異咽腔粘膜の劇しい触痛亚に出血（綿棒擦過に上 る）は次第に消退して行き，遂に全く触痛を感じなくな 马.

4. 正常の奥咽腔は全く触痛も出血もこれを欠き，又 剝離上皮の塗抹像も正常の上皮細胞方稀に見られる程度 で，遊走細胞は殆んど見られない，

等のことから，鼻咽院炎の存在並にその経過を上記の 観察結果によつて決定し且つ追求する事が可能になつた のである。

そこで今回はこれら舆晒腔㷋観察基潐に従つて，まつ 正常蕃㸶腔の細菌叢を観察し，次に鼻胭腔资患者の細菌 丵が，鼻咽腔炎の絽過といかなる関係にあるかる追求し た。

観察記載法に関しては

主要臨休像として, 鼻咽腔粘膜の触痛と, 後奥漏るあ げ，その程度に応して三段階に分け記載した。

即ち触痛は，強い(H) 弱い(十) 無し(一)

後鼻漏は，多い(H) 少い(十) 無し(一)

上皮㓌抹像では

剝離数を非常に多い(H) 多い(H) 少い(+)

の三段階に分け図形で記入した。

白血球，淋巴球，赤血球は，すへて遊走細胞として一 括し，やはり遊出量を上述の如く三段階に分け図形で記 入した。

一方細菌は，上皮塗抹像と共に毎日又は隔日塗抹標本 並に血液寒天培責を行い，その消長を観察した。

その記載法及び結果は次項に記す通りである。 


\section{3. 瀵察結果}

1 準抹標本

この菌検查法に括いて最も特徵的な事は, 所謂細菌学 的な菌培養分離法等を行う事なく，主として局所の分泌 夜の塗抹染色標本による観察を行い，環境の变化による 細菌像をそのままに見る事により，逆に環境，即ち局所 の炎症性变化を推測しょうとした事である ${ }^{23) . ~}$

そこでここでは単なる鏡梌像による菌の形態的観察 であるので，ここに観察した結果は単に形態的記載に止 まるのである．即ち鏡検像では，ブドウ球菌，レンサ球 菌，双球菌，大型双球菌，棹菌，の像が主なもので，そ の量的関係を写真で示寸如く，

非常に多い (1，2 図) や中多小 (3，4 図)

存在する (5,6図) 見当ら如

の四段階に分けた。

正常鼻咽柼は第 I 表に示寸如く，5 例中 2 例は全く菌 が見当らず，他の3例では，検出されてむ，洤珠像で は，菌型は双球菌で菌量は僅かであり，培養された菌種 は，非溶血性ブドウ球菌が主なものであつた。

第 I 表

\begin{tabular}{|c|c|c|c|c|}
\hline \multirow{2}{*}{ 戱 } & \multirow{2}{*}{ 㓱 } & \multicolumn{2}{|c|}{ 梁 珠 像 } & \multirow{2}{*}{ 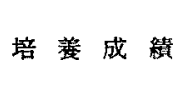 } \\
\hline & & 菌 型 & 菌 量 & \\
\hline & 1 & 双 球 & $t$ & 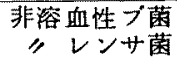 \\
\hline & 2 & - & - & - \\
\hline & 3 & - & - & - \\
\hline & 4 & 双 球 & + & 非溶血性 ブ菌 \\
\hline & 5 & 双 球 & + & 非溶血性 ブ菡 \\
\hline
\end{tabular}

宜咽腔炎患者においては，鼻咽腔の局所治療のみを行 い，全身治療は一切これを行わず観察した，局所治療 としては，1\% $\mathrm{ZnCl}_{2}$ 水溶液主として毎日又は隔日 に粘膜上に塗布，必要に応して5000 倍 adrenalin 2\% Xylocaine 併用したが antibiotics その他の抗菌物質 乃至化学療法は一切用いなからた。

観察対象としては，形態上の出現菌種及び菌量の变化 之，鼻咽腔臨床像（鼻咽腔の触痛及び後鼻漏）及び上皮 鋈抹像とを比較した。

これとよって鼻咽腔资の経過を示すところの前記鼻咽 腔臨床像及び上皮叙抹像の变化が, 細菌丵の消長とよく 一致することがわかつた。

そこでこの細菌鋠の変化を次のよらなの型に分類でき た（第1 図参照）.
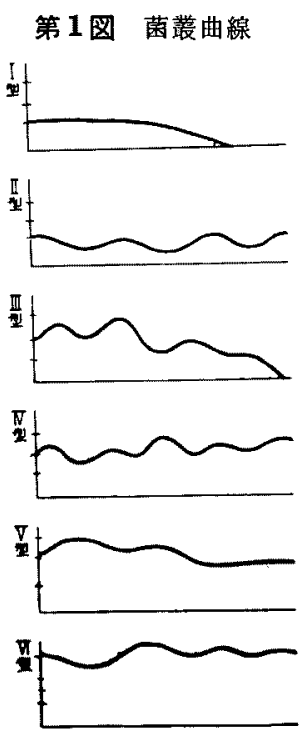

I 型：菌叢（菌種菌量） の変化少く，急速代菌の消 失寸る型

型：菌丵の変化は少 いが，菌は秱失しない型

四型：菌丵の变化屾大 きいが，菌は消失する型

N 型：菌哑の変化大き く, 菌は消失しない型

V型：菌量は多いが， 長期の治療で菌叢の固定化 する型

V型：菌種，菌量共に 多く，長期の治療でも菌が 消失しない型

但し，菌叢の固定化と は，菌量の減少よりも寧ろ菌種が 122 種の非病性細菌 に固定化して，常に一定菌のみ検出されるよ5になる事 としたのである。

なお，この菌種，菌量の変化を図示したのが，第１図 であり,これを菌叢曲線と名づけた。

以下夫んの型に対応する定型的な症例 6 例を挙げて説 明する。

症例 1 菌叢の変化少く, 容易に菌の消失する型

39 才 ○ (症例 No. 32) 主訴：鼻咽腔乾燥感

2〜3 日前より舅咽腔に乾燥感があり，1 日前より症状 が強くなつたので来院した。

番鏡所見では異常なく，鼻咽腔の触痛が唯一の所見で あつた，初馀上皮塗坤像で剝離度 $(H)$ ，遊走細胞(十) であつたが，第 10 病日以後はいつれる $(+)$ に減少して いた. 細菌像では，第 12 病日から第 14 病日にかけ菌量 は減少した，主訴も殆んと軽块し，その後全く菌は検出 されず，又主訴子消失した。

この症例の如く，鼻咽腔触痛が唯一の所見で，上皮塗 抹所見でも僅かな变化しか認められず，比較的短期間に 主訴消失した症例は，菌丵の変化も僅かで，急速に菌は 消失した。

このよらな菌叢の変化を示するのをＩ型とし71 例中9 例で $13 \%$ を占めていた。

症例 2 菌叢の变化は少いが，菌の消失しない型 46 才。 (症例 No. 34) 主訴：盛咽䧑異物感 約 2〜3 週前より奥咽腔に 異物感があつたが，他に自 
第 1 図

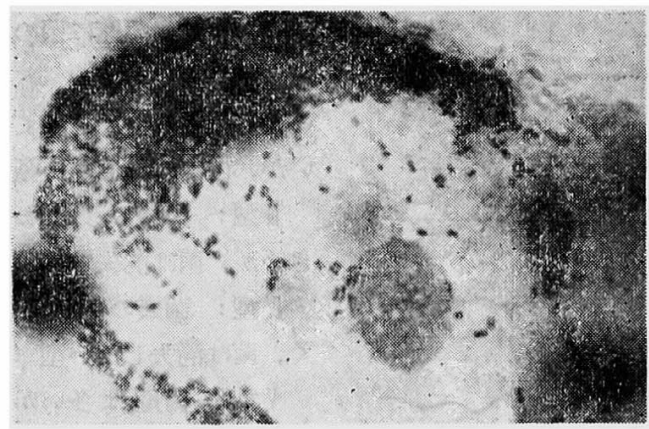

第 3 図

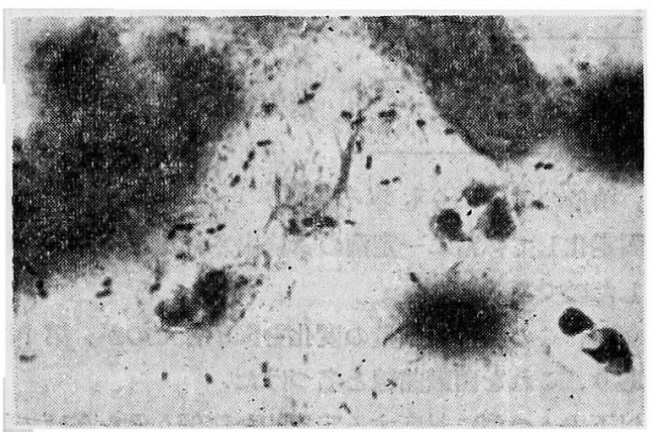

\section{第 5 図}

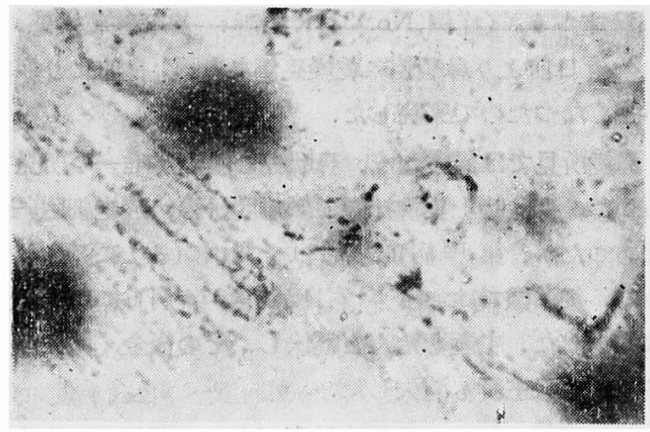

第 2 图、

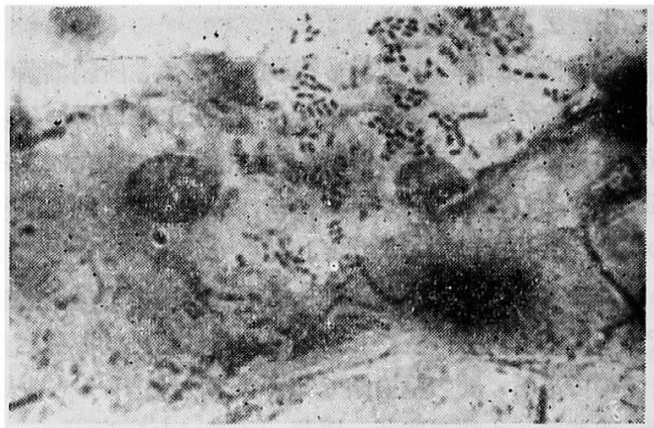

第 4 図

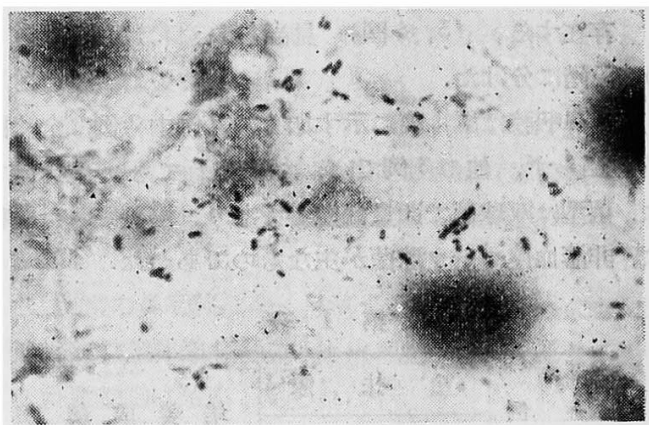

第 6 図

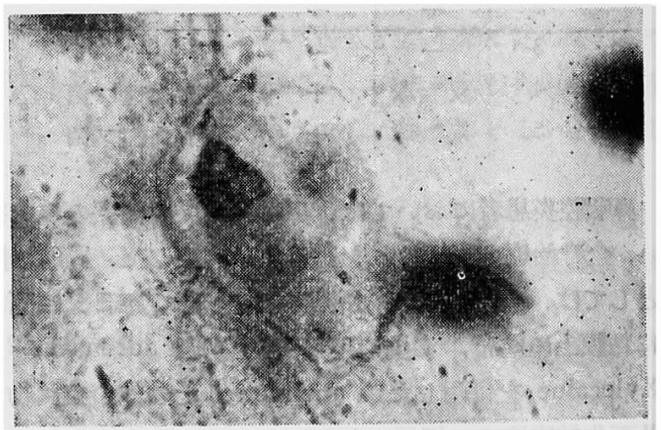


覚症状がないので放置しておいたところ，2〜3日前より 主訴が強くなり，来院した。

鼻鏡所見は異常なく，症例 1 と同様，鼻咽腔の触痛が 唯一の 所見であつた．その後隔日の治療で約 12 病日以 後に一時的の菌量の減少を示した事が 2 回程あつたが， 47病日の治療観察にも抱らず，少くともこの期間内には 主訴及び菌量の減少は見られなかつた。

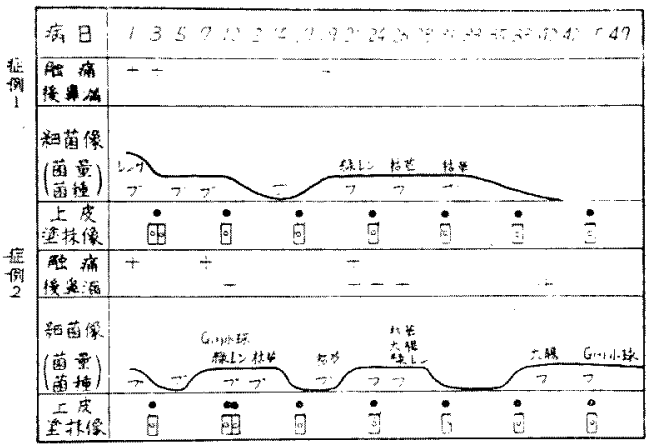

上皮塗抹所見は症例 1 と似ていたが，触痛が再発する 場合には，上皮涂坤像でも僅かながら䟝離度が增した。

この症例の如く，初診時から 1 2 週は，症例 1 と同 様の経過であつても，触痛及び上皮叙坤所見で增悪が繰 返され，主訴つ消失しない例は，菌の消失も見うれなか った.

このような菌叢の変化を示するのを】型とした。71例 中 17 例で $24 \%$ を占めていた。

症例 3 菌叢の变化が著しいが, やがて菌の 消失する型

38才 ㅇ (症例 No. 38) 主訴：鼻咽腔痛

数年来風邪をひき易くなつているが，10日前より軽い 奥閉感之勫咽腔の痛及を感ずるようになつた。楀鏡所見 では，下番介，中舆介共やや発赤が認められた他は異常

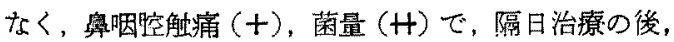
4〜5 日間は俥快した。第 17 病日に鼻咽腔触痛 $(H)$ ，溶 レン菌㭘出，第 21 病日には菌量 (H) となつた。

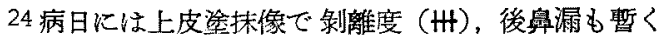
皖いた。しかし 38 病日頃から殆えど主訴消失し，菌の 種類, 菌量共仁減少し, 上皮細胞剝離度, 遊走細胞子減 少した。

この店例の如く，触痛，後箅漏，上皮塗抹像所見と細 菌叢との間に消長のづれはあってもある程度の相関関係 を有しながら変化し，やがて菌の消失する場合を】型に した 71 例中 8 例で $11 \%$ を占めていた。

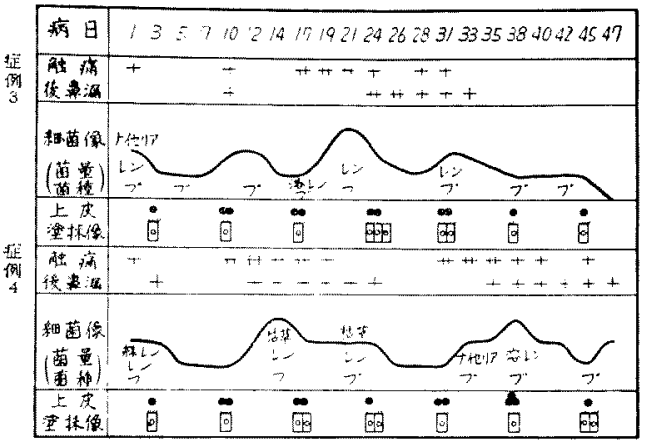

症例 4 菌叢の变化著し?, 菌の消失しない型 21 才 $q$ （症例 No. 31）主訴：頭痛

症例 3 と同じく，鼻咽腔臨床像，上皮塗坤像と細菌灇 との問に相関々倸をある程度示しつつ変化したが これ ら臨床像及び上皮㳊抹像が增悪を繰返し，主訴も軽快せ ず，菌量も減少しないで增加が絽返された。

このような菌譀の変化を示したものをN 型とした. 71 例中 24 例で $34 \%$ を占めていた。

症例 5 菌の種類, 菌量共に多く, 長期の治療後 に菌叢の固定化を見る型

45 才 + (症例 No. 33) 主訴：後舅漏

鼻䦎感と後鼻漏が数年来あるが，蓄膿と診断された事 はない，外来でレ線榆查，上顎洞穿刺洗深の結果，副番 腔炎は䇥い事が確認された。連日の治療に抵抗したが， 40病日頃から菌量の減少を見ると同時に後鼻漏も殆んぞ 消失した．しかし上皮塗抹像では線毛上皮の变形が，全 病日を通じて認められた。

この症例の如く，菌量多く，又上皮細胞の変化も強い 場合で我, 約 1 力月で主訴軽快し, 菌量減少し, 菌叢の 固定化したるのをV型とした。 71 例中 4 例で $5 \%$ を占め ていた.

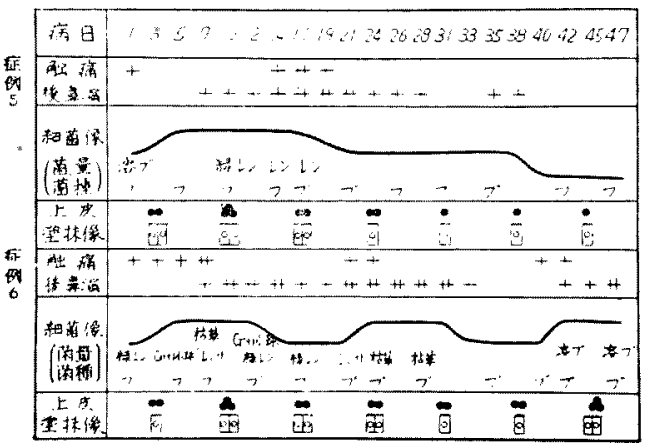


症例 6 菌の種類, 菌量共に多く，長期の治療で も菌叢の固定化しないるの

54 才 $\delta$ (症例 No. 3) 主訴：後奥漏

症例 5 と同様, 鼻開感と後鼻漏は激しかつたが, 触痛 は軽度であつた．X線，上须洞試験穿刺等の検查で副鼻 腔炎は否定されたが，菌の種類，菌量共に多く，上皮塱 抹像では線毛上皮の变形強く，遊走細胞も多かつた。

連日の治療泜抗し，全く主訴の消失なく菌叢の固定 化も見なかつた。

この症例の如く，連日の治療にも抱らず，臨床像及び 上皮涉抹像がいつ迄も変化の強い場合は，菌種，菌量共 に多く，菌叢の固定化を見なかつた。このような菌叢を 示すものを型とした，これは以上の分類によれば，い わゆる慢性勫咽腔炎と考えられる型である，71 例中9 例 で $13 \%$ を占めていた。

\section{第 2 図}

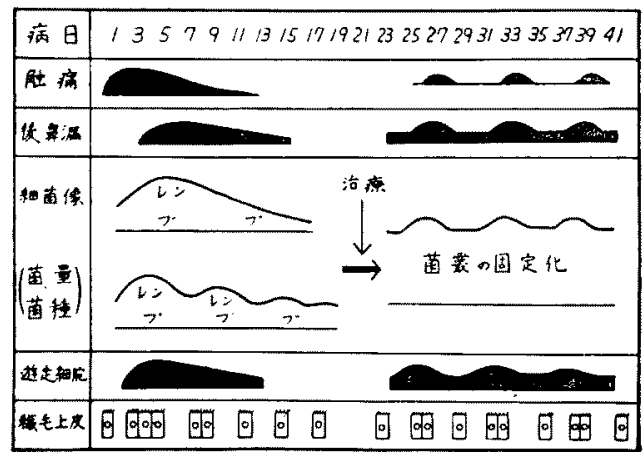

以上の6症例から判る如く, 菌種, 菌量の変化は, 触 痛, 後鼻漏, 上皮塗抹像の変化とよく一致していた. 即 ち第 2 図に示す如く，急性鼻咽腔炎では，まつ触痛が出 現し, 次に上皮剥離細胞の数が增加し, 遊走細胞も增加 した，1〜2日遅れて，後鼾漏が堌加したが，この頃から 細菌の菌量は急激に增加が認められた。毎日又は隔日の $\mathrm{ZnCl}_{2}$ 鼻咽腔塗布治療を行うと, $1 \sim 2$ 週頃から次第に，

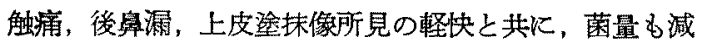
少し始めた。

一方慢性炎では, 連日の治療にも抵抗し，菌量も多い ものが普通である，時には第 $V$ 型の如 $く$, 菌裳の固定化 の見られるるのであっても，後奥漏及び線毛上皮刨離細 胞や遊走細胞等は殆んど定常的に存在している.これら のうち，時に一過性の增悪を示し触痛が現われる場合が ある (И型) がこのよらなときは，菌量が著しく增加す る.これは慢性奥咽腔炎の急性再発症である。
即ちこれら菌坟曲線の山（即ち菌量の增加）は，偟床 所見 (触痛, 後鼻漏) や, 上皮塗抹像と時相はややつれ るが，完全に平行し，菌そのものの消長を，そのまま奥 咽腔炎の経過, 特に急性增悪を表和すむのといら事がで きる。

\section{I培盖成績}

1の㭘查法の結果，塗抹像による菌叢曲線が，鼻咽腔 炎の経過上よく一致し，消長する事が判つたが，この菌 検査法では立場を換克て，鼻咽腔粘膜上の培地から，血 液寒天培地に置換された状態の菌の動態が，菌叢曲線と いかなる関係にあるかを追求した。即ち1で行つた鼻咽 腔に括ける細菌の形態的観察と共に, 従来の培養法に従 つて血液寒天培地で培着同定した菌種と, その集落の状 態に注目し，菌叢曲線即ち鼻咽腔炎の経過との関係を比 較観察した。

正常鼻咽腔の培養成續は，第 I 表の如くである.

a) 菌種と菌叢曲線

菌蕟曲線作成と同時に得られた培養成績は第 II 表の如 くで，その一は菌種と菌讙曲線の関係を示したたるので ある.

\section{第 III 表}

(その $\rightarrow$ )

\begin{tabular}{|c|c|c|c|c|c|c|c|c|c|}
\hline & $\begin{array}{l}\text { 韭 } \\
\text { 溶 } \\
\text { フ }\end{array}$ & $\begin{array}{l}\text { 溶 } \\
\text { ブ }\end{array}$ & $\begin{aligned} & \text { 非 } 2 \\
& \text { 溶 } 2 \\
&+\end{aligned}$ & 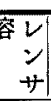 & $\begin{array}{l}\text { 粶 } \\
V \\
y\end{array}$ & \begin{tabular}{l|} 
肺 \\
双
\end{tabular} & $\begin{array}{c}\mathrm{G}^{ \pm} \\
\text {桿 }\end{array}$ & $\begin{array}{l}z^{z} \\
\sigma \\
\text { 他 }\end{array}$ & \\
\hline 1 & 9 & 0 & 5 & 0 & 1 & 2 & 2 & 0 & ${ }^{9}$ (侧) \\
\hline $\mathbb{1}$ & 14 & 10 & 5 & 0 & 3 & 6 & 4 & 2 & 17 (例) \\
\hline 目 & 8 & 2 & 5 & 0 & 2 & 0 & 1 & 0 & 8 (例) \\
\hline N & 10 & 14 & 9 & 3 & 6 & 11 & 6 & 4 & 24 (例) \\
\hline V & 3 & 2 & 2 & 0 & 1 & 1 & 1 & 0 & 4 (例) \\
\hline $\mathrm{Vl}$ & 7 & 3 & 3 & 0 & 2 & 2 & 2 & 3 & 9 (例) \\
\hline \multicolumn{10}{|c|}{ (その二) } \\
\hline $\begin{array}{c}\text { 純培盖) } \\
\text { (1型 }\end{array}$ & 2 & 7 & 0 & 0 & 0 & 2 & 0 & 0 & 11 (例) \\
\hline $\begin{array}{c}2 \sim 3 \text { 種 } \\
\text { 発育型 }\end{array}$ & 18 & 5 & 16 & 0 & 0 & 2 & 4 & 0 & 22 (例) \\
\hline $\begin{array}{c}\text { 多種湜合型 } \\
\text { (4種以上) }\end{array}$ & 31 & 19 & 13 & 3 & 15 & 18 & 12 & 9 & 38 (例) \\
\hline
\end{tabular}

これらの菌種を全症例に就いてみると，非溶血性ブ菌 >溶血性ブ菌>非溶血性レンサ菌>肺炎双球菌>緑レン 菌 $>\mathrm{G}( \pm)$ 桿菌〉その他〉溶血性レンサ菌の順に多く検 出されたが，

菌叢曲線の型別に菌種の検出率を見ると， 
i）急性增覀を反覆する型（II 型， N 型）に溶血性ブ 菌、肺炎双球菌が多かつた。

ii）菌叢曲線の型関係なく 非溶血性ブ菌は，どの 症例にも平等の検出率で多く認められた.

iii）溶血性レンサ球菌は，急性堌悪反覆型でも变化の 強い、型にのみ認められた。

iv）その他の菌種は，菌叢曲線の型之特に深い関俰は 認められなかつた。

ここで鼻咽腔炎の最も経過の良いＩ型の症例と，急性 増悪反覆型即ち $N$ 型の应例を挙げて比較すると, 第 3 図 の如くであるが，この場合の急性增覀反徱型の菌種とな つている溶血性ブドウ球菌は鼻咽腔资の增大時に菌量も 增加して括り，炎症の軽快と平行して溶血性ブドウ球菌 の菌量は少なくなつたが，最後迄消失する事はなかつ đ.

第 3 図

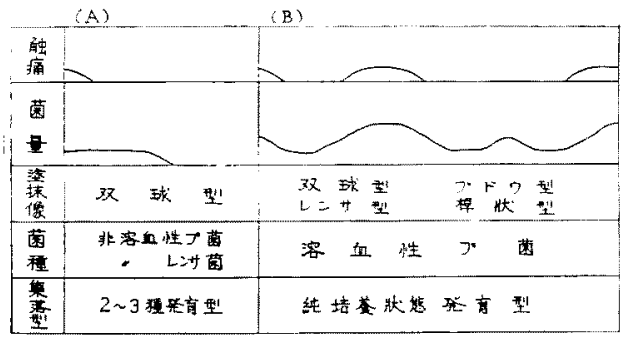

また與味ある事は，この症例の如く同一菌種である溶 洫性ブドウ球菌の菌量の消長が絽返される傾向が強い事 で,この事からも新しい細菌の感染が资症を左右すると いらのでなく，炎泟の発来が先つ第一義的であるという 事があり得ることが考学られるのである.

要するにこれら番咽腔炎の経過中に例兄ば急性增悪時 溶血性ブドウ球菌以外の菌種が出現し始めて，その 菌種が今迄の菌種である溶血性ブ菌を抑えて発育すると いら事はなからた。

次㳊興味ある事恃，鼻咽腔炎患者で歴埃を吸ら機会が 多い環境にいる人や，カーボン工場等で值接炭粉を吸ら 譏会の多い人が，すべて，急性增悪反覆型の $\mathbb{N}$ 型か，慢 性炎のV型に限つて認められた事である。しかもその数 は，N型V型全症例 33 例中 10 例で，33\%を占めてい た.

第 $N$ 表括弧内数字がその症例数を示している.

更に與味ある事実は，この10 例中溶血性ブドウ球菌 功常に純培養状態で検出された 4 症例では，すへて鼻咽
膑炎の臨床症状西強く，上皮涂抹像所見著しい炎症性 変化を示していた事である。

第 IV 表

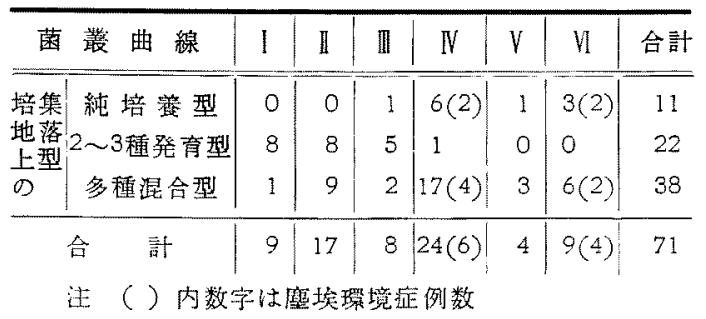

b）集落型上菌叢曲線

血液寒天培地上の集落の型に注目してみると, 全症例 が，次の3型に分類できた（写真 X参照）.

1.1 種の菌が所謂純培盖状態発亩する型

2.2 2 3種の菌が発育する型

3. 多種 (4 種以上)の菌が混合して生える型

この集落の型と菌種との関係は，第四表その川に示す 如くである. 即ち

i）純培盖状態に発育する型では，溶血性ブドウ球菌 が多かつた。

ii）2〜3種の菌が発青する型では，非溶血性ブドウ 球菌，非溶血性レンサ球菌が多かつた。

iii）多種混合型では，非溶血性ブドウ球菌が多く，溶 血性レンサ球菌以外の他の菌種が 同じ程度に 検出され た.

これらの各集落の型は，症例で殆んど一定しており， 経過によつて，集落の数の增隇はあつても型の変化は殆 えどなからた。

この3 型の集落型を鼻咽腔约の経過と共儿菌叢曲線と 比較してみると,

1。純培盖状態に発育する型は，急性增恶を反覆する 型豆含めて，慢性の鼻咽腔炎に見られる事が多く，菌叢 曲線では（N型、V型、V型）に殆んど集つていた。

2. 2 3 種の菌が発育する型は，䠦床的には比較的容

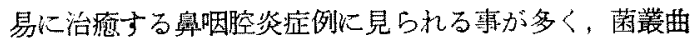

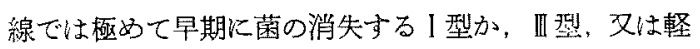
度の再発を絽返す】型に殆んど集つていた。

3. 多種混合型では，一般にあらゅる症例㐳認如られ たが，菌が全く消失して了ら型（１型，而型）には殆ん ど認められなかった。

第N表は以上の事実を表にまとめたものである，即ち 急性增恶を反覆して臨床上治ゆの困難な型( II 型, IV 型) 
及び慢性炎の型（V型，VI型）に注目してみると，集落 の型が，純培養状態発育型か，多種混合型以多くが集 り，又菌種に関しては，第 $V$ 表その 1 の如く, 病原性球 菌（溶血性ブドウ球菌，肺炎双球菌等）が多数検出され る事が多く，特に純培盖状態でこれらの菌が検出される 場合は，率㸶腔炎の主要臨床像も顕著な事が多からた。

更に與味ある事実は，第四図Bの如く 塗抹像で多種 の菌が認められても, 血液寒天培地上に純培咅状態に菌 が発育する場合は，すべて藇咽腔炎の主要臨床が顕著で あつた事である。

$$
\text { 4. 小括 }
$$

鼻咽腔炎の消長に平行して消長する細菌の状態を镜察 するために，まつ正常奥咽腔の状態を観察し，次に鼻咽 腔炎の症例に就いて観察したところ，

i）正常鼻咽腔では，菌の検出できなかつたものが5 例中 2 例，他の 3 例では少数の菌を認めた. 即ち塗坤像 で少数の双球菌を認め, 培盖では, 少数の非溶血性ブド ウ球菌及び非溶血性レンサ球菌を認めた。

ii）䶊咽腔炎では $\mathrm{ZnCl}_{2}$ 䤠布のみの治療に上り菌が 完全に消失する例は非常に少く，完全に消失した症例は すべて急性炎であつた。

iii）囱咽腔炎の経過によつて消長する菌種菌量をグラ フで 图示寸ると，6 型の菌對曲線に分類できるが，これ らの菌の消長は，臨床像，上皮塗抹像等に上る鼻咽腔炎 の経過とほぼ一致する，そこで逆汇菌丵曲線は，奥咽膑 炎の経過を示するのといえる。

iv）菌鋠曲線では一般に同一菌種の菌量の変化が主々 して示される傾向が強からだ。しかも菌量增加と鼻咽腔 炎の增悪とは上く平行し，特に溶血性ブドウ球菌が純培 養状態で検出された症例では，菌量と炎症性変化がょく 一致した。

v) 集落が 2 3 種混合して生える型, 純培養型, 多

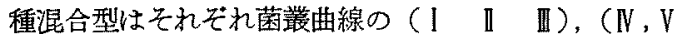

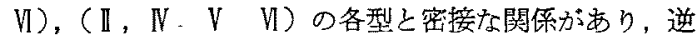
に培羡集落の状態から鼻咽焢炎の経過をある程度推定で きると思 5. 即ち2〜3 種発育型は容易に治瘾江向万傾 向があるが，純培養状態や 多種泿合瑟炕発育する型で は慢性化の傾向があつた，特に溶血性ブドウ球菌の純培 堆発育型は，菌丵曲線の（N 型， V型）之密接な関係が あり，炎症增悪と結びついていた。

vi）溶血性ブドウ球菌の純培苗状熊発育の場合は，急 性增恶又は慢性炎でも非常汇強、资症性の再発の場合が 多く，特に潔抹像で多くの菌種が認められても，培盖成
績け純培養状態に発育する場合，急性增覀に関係が深い。 と思われる。

vii）塵埃及び炭末は何らかの意味で 鼻咽腔炎の 增覀 に関係していた。

\section{5. 動物 実験}

1 実駼目的

鼻咽膑細菌叢の臨床的観察により，塵埃環境が細菌叢 の状態に 密接な関係があるように思われた（第N表）。 そこで溶血性ブドウ球菌及び宸末は粘膜行対し，炎症增 悪に関与する事が推定されたのでどの程度の变化が認め られるものかを実験した。

病原性球菌の代表としてブドウ球菌 209p を用い，家 束鼻咽腔粘膜に注入した場合に，その粘膜がいかなる反 応をするか，又炭枌が単独で入つた場合と，菌液を混合 して用いな場合とで炎症性変化に差があるかを観察し， 臨床的観察から考兄られた次症增悪関係する因子の吟 味をした。

\section{II実験方法及び結果}

1. 正常家乘蓈咽腔粘膜組織像及び細菌像の所見

2. 同じく鼻咽腔にブドウ球菌 $209 \mathrm{p}$ 注入後の 細菌像 之粘膜像の変化

3. 同じく番咽腔に 炭粉注入後の 細菌像と粘膜像の変: 化

4. 同しく鼻咽腔にブドウ球菌 209p と炭粉を混合し たものを注入後の細菌像と粘膜像の変化

1. 正常家鬼奥咽腔細菌像及び粘膜組織像の所見

a）方法：10日以上動物小屋飞特いて 飼育した 2.5 kgの家束 6 羽を空気烃塞で殺し，直ちに断頭，気管側か b上咽頭を開き，軟口盖鼻側面上の細菌塗抹標本作成度 び培盖後，10\%フオルマリンに固定，パラフイン包埋 とし，摽本を作成し，へマトキシリン・エオシン染色後 鏡検

b) 結果：正常家象鼻咽腔細菌叢は, 表 $V$ の如く, グ ラム陰性桿菌が主で，他にグラム陽性小球菌，ブドウ球 菌，变形菌等が極く少数例に認められた，又粘膜組織像:

第 $\mathbf{V}$ 表

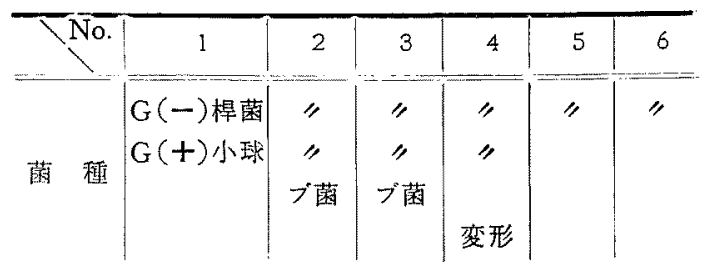


は写真（1)の如くで，鼻哂腔には浸出物はなく，粘膜上 皮は線毛を有するる層の高円柱の上皮細胞とその間に介 在する杯細胞よりなり，底部认補充細胞が存している。 上皮細胞間の結合む密である. 上皮下固有層は少数の毛 細血管を有する疎性結合組織よりなり，炎症性変化は認 められない，又数例に执いては，固有層にりンパ湮胞の 発避がみられ，その部位で，上皮に化生がみられた。

2. 正常家鬼悬咽腔にブドウ球菌 $209 \mathrm{p}$ 注入後の 細菌像之粘膜組織像の变化

a）方法：10日以上動物小屋に扎いて飼育した $2.5 \mathrm{~kg}$ の家鬼 23 羽に $209 \mathrm{q}$ 菌液として生理的食塩水 $1 \mathrm{cc}$ Kl 白金子の割合で作つたものを，0.4cc ビニールチユーブ を通して家象鼻咽腔に注入，予め定めた期間(3時間， 6 時間, 12 時間, 1 日, 3 日， 1 崌， 3 週，1力月), 飼 育後実験 1 と同栐に処置し，1 回注入後のもの 18 羽と， 6 回連日注入後のもの 5 羽の 2 群に試いて，前述の (1) におけると同様な万法で観察した。

b) 結果：細菌裳については, 注入ブドウ球菌の菌量 の追求と，その他の常在菌堂の变化を観察した，一方粘 膜組織の炎症性変化としては，表りの如く，自咽腔内浸 出物，線毛上皮々上皮細胞間の変化，上皮下固有層の獎 液及び白血球の浸潤，血管拉張等の急性の炎症性変化を゙

第 VI 表

\begin{tabular}{|c|c|c|c|c|c|c|c|c|c|}
\hline & 間 & $3 \mathrm{~h}$ & $6 \mathrm{~h}$ & $12 \mathrm{~h}$ & ${ }^{1} \mathrm{D}$ & $3 \mathrm{D}$ & $1 \mathrm{~W}$ & $3 W$ & $1 \mathrm{M}$ \\
\hline & 注入ブ菌 & H & H & H & $H$ & + & \pm & \pm & - \\
\hline 細 菌 叢 & その他の菌 & & 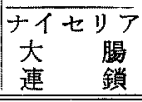 & & $\begin{array}{ccc}イ & \text { ニ } \\
\text { 大 } & \text { 腸 } \\
\text { 変 } & \text { 形 } \\
\end{array}$ & $\begin{array}{l}\text { チイセリ } \\
G(ー)\end{array}$ & $\left|\begin{array}{r}\bar{G}(-) \text { 球 } \\
\text { 桿 }\end{array}\right|$ & $\begin{array}{r}\bar{G}(-) \text { 球 } \\
\text { 桿 }\end{array}$ & $\begin{array}{r}\overline{G(-)} \text { 球 } \\
\text { 棹 }\end{array}$ \\
\hline 上皮上 & 曼 出物 & - & + & $H$ & $t$ & - & - & - & - \\
\hline $\begin{array}{l}\text { 上友層 } \\
\text { 炎症性変化 }\end{array}$ & $\begin{array}{l}\text { 線 毛上皮 } \\
\text { 上 皮 間 }\end{array}$ & $\begin{array}{l}+ \\
+\end{array}$ & $\begin{array}{l}+ \\
+\end{array}$ & - & - & - & - & - & - \\
\hline $\begin{array}{l}\text { 上皮下固有層 } \\
\text { 炎在性恋化 }\end{array}$ & $\begin{array}{ll}\text { 水 } & \text { 腫 } \\
\text { 白 血 球 } \\
\text { 血管 拡 張 } \\
\text { 円形細胞浸出 }\end{array}$ & $\begin{array}{l}t \\
+ \\
+ \\
-\end{array}$ & $\begin{array}{l}H \\
H \\
+ \\
-\end{array}$ & $\begin{array}{l}+ \\
+ \\
+ \\
-\end{array}$ & $\begin{array}{l}- \\
- \\
- \\
+\end{array}$ & $\begin{array}{l}- \\
- \\
-\end{array}$ & $\begin{array}{l}- \\
- \\
-\end{array}$ & $\begin{array}{l}- \\
- \\
-\end{array}$ & $\begin{array}{l}- \\
- \\
-\end{array}$ \\
\hline
\end{tabular}

観察した。これら变化の程度を三段階に分けて表示し た.こ孚をグラフにしたのが第4図である。

第 4 図

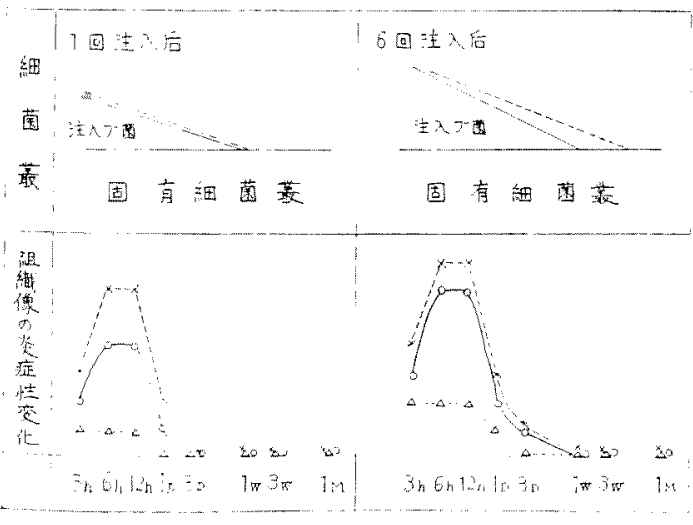

即ち1 回注入のものでは

i) 注入ブドウ球菌は, '注入後 1 週間以内に消失する
が，他の常在細菌欉には变化は認められない，

ii）粘膜組織には，菌注入後 3 時間で既に炎症性変化 が認められるが (写真 I )，6時間 (写真 III)，12時間 （写真N）を頂点として，急速に消䢐して行き，3日後に は粘膜は正常像にもとつた（写真V).

次に 6 回連日注入のものでは

i）細菌叢は前群之同じく，注入ブドウ球菌の急速な 減少を来寸１日目迄の菌量は初めの群より多いが，1 週後には，消失する，しかし固有細菌欉には変化はなか つた.

ii）粘膜組織の炎症性变化は前群之同様の経過を示す が, 炎症の程度は強く, 正常像にもどる日時が多少遅延 された。

以上の如 $<$, 菌液 1 回注入群でも, 6 回連日注入群で も，粘莫の炎症性変化は一過性で，乙かも炎症が軽い事 がかかつたが，菌液の粘膜上からの刺激のみです，炎症 性変化を起し得て，しかもその反応は注入ブドウ球菌の、 
登抹，培盖成績と大体一致して推移する事が認められ た.

3. 正常家鬼與咽腔に炭粉注入後の細菌像亡粘膜 組織像变化

a) 方法：10日以上動物小屋に扎いて飼育した $2.5 \mathrm{~kg}$ の家象 8 羽に，生理的食塩水 $1 \mathrm{cc}$ 中に 3 白金子の減菌 炭粉を入れた液 $0.4 \mathrm{cc}$ をビニールチユーブで鼻咽腔に注 入, 奏戨 2 同様一定期間飼育後，1 回注入羣 6 羽之 6 回 連日注入群 2 羽の 2 群に就いて組織学的に観察した。

b) 結果：細菌叢は正常家鬼奥咽腔の固有細菌叢と思 われる表】の菌種に限られており，特に菌量の增加は認 められなかつた。そして，1 回注入群之6 回連日注入群 との間には有意の差は諰放られかつた。

粘膜組織は，炎症性変化は殆えど無かつた。しかし悬

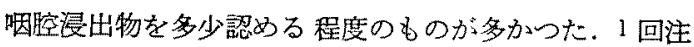
入群より，6回連日注入群の方がや凤応が強く，反応 持続期間も多少遅延していた。

4. 正常家鬼學胭腔にブドウ球菌 209p と炭粉を混 合したものを注入後の細菌叢と粘膜組織像の変 化

a) 方法：実験 2 同様の正常家躳 17 羽に，同棣の ${ }^{209} \mathrm{p}$ 菌液 $1 \mathrm{cc}$ に 3 由金子の減菌炭粉を加え，これの $0.4 \mathrm{cc}$ を実験 2 同様鼻咽腔に注入，前述の諸群上同様の 期間飼育後殺し，1 回注入群 13 羽之6 回連日注入群 4 羽 の観察をした。

b) 結果：細菌叢についてみると，注入ブドウ球菌 は，第 4 図の点線の如く，1回注入の場合には菌単独注 入の場合と殆えど同じ推移を示した。又6回注入の場合 は，菌単独注入の場合より多少消失期間が逯延された。

固有細菌叢には，実験 2 同様，著变は認められなかつ た。.

組織学的には，第 4 図の如く，悬咽腔粘膜の炎症性反 応の程度は比較的強く，1回注入群では，注入後 3 時間 “で(写真V) 既に实娩 2 よりやゃ強い炎症性反応がみられ た. 乙かし炎症が 6 時間 (写真VII)，12 時間 (写真VII) を 頂点として急速に溜退する点は，菌単独注入の場合と殆 んど同じであつた。6回注入例では，1回注入例より粘 膜の炎怔性反応の程度は強かつた（写真 X)，粘膜の炎 症性反応は, 菌, 炭粉混合液 1 回注入例では, 菌単独注 入例上り高度であつたが，菌，宸粉混合液 6 回連日注入 例では, 菌単独注入例と比較して粘膜の炎症の強さの差 異が少なからた。

$$
\text { III 小 括 }
$$

家鬼の正常鼻咽腔に乱いては，病原性ブドウ球菌 209 p の注入に際して，家鬼が実験動物で最もこの菌種に感 受性が高いとされているが，固有細菌叢には殆んど変化 は認められず，粘膜に柽度の一過性の炎症性変化を起し たに過ぎなかつた，但し，菌增殖㑯向と，炎症性变化の 消長とが一致した事は興味ある事実であらた。即ら一般 に菌は培善後 2〜3時間で增殖を始め，15〜18時間で最 高に達し，後は 30 時間位迄減少するすのたが，今回の 实験の炎淀性変化も，菌增殖の消長之よく一致した。

一方，この菌液に炭粉が加わると少くとも粘膜の炎症 性変化は，菌単独で注入された增合よりも增加される事 が明らか上なつた。

即ち $209 \mathrm{p}$ 菌液と, 隇菌炭粉を混合して注入すると， 注入ブドウ球菌の消失経過は，菌単独使用例と同様であ るが，粘膜の炎症は前渚より強い，注入ブドウ球菌の增 殖及び消失過程には，实験結果から㞸粉の存在上りる固 有細䔉叢の影響がより大きな意義をるつように考えられ たが，細菌学的な子䚚実䟻によれば影響がない事がわか つた，又一方粘膜の炎症性反応は注入した菌，炭粉混合 液の影響によるとこるが大さい，しかしてこの場合の炎 症が菌単独注入の場合より強いのであるから，㞸粉の混 在が炎症の㙕䔡に対して，関係をるつと考えてもよいで あろ5.今回の実験で宸粉を菌液に混合して使用寸る場 合，炭粉が菌の発育に及主影䍌を考慮して子備実験した ところ，影響はみられなかつた，唯、菌液がある濃度以 下の場合，菌の吸着が炭粉の量に比例しておこり，吸着 した菌が培地に発育する事がかかつた。そこで菌が炭粉 に吸着されて粘膜に作用する場合には，粘膜面に拈ける 菌の量心，菌液単独に批るよりる多く，そのために粘 膜に強い炎症性反応を起し得るものと考兵られる。菌炭 粉混合液の6回連日注入群にみられた粘膜の炎症は，1 回注入群に郝けるよりも多少性強かつたが，その差は最 初に予想した程著しくはなかつた。これは、1 回注入の 場合の粘膜の炎症が軽く，24時間で殆んど軽仭している ので，炎症の著しい增悪を起し得なかつた一つの原因上 考光られる。

要するに臨床的に 鼻咽腔炎の增悪に病原性ブドウ球 菌、炭末等が関係している置が予想されていたが，今回

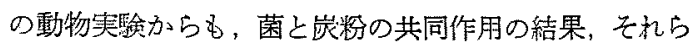
が炎应增悪に関係する事が認かられたのである。

\section{6. 紷括及び考按}

鼻咽腔炎が展 々全身諸疾患と密接な関係 17) 18) にある 事が当教室の研究テーマとなつて括り，鼻咽腔炎の䛦断 に関する研究が進んで，今日では，その炎症の寒を態を 
ぼ正確に把握できるようになつた，今回はこの畺咽腔资

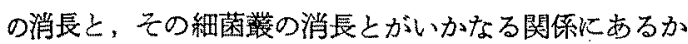
を観察し，更に炎症の増悪に関する因子に就いて检討す るのが目的であつた。

\section{1. 塗玶像に関する検討}

炎症之その細菌叢の関保は，それらが相互に影響し合 って，それぞれ焱症像や細菌叢を示するのであり，その 椙互関係の結果として炎症巣を理解する事が重要であ る.この観点に基いて，今回は宿主である偎咽腔粘膜と 寄生体である細菌叢の相互関係を明らか炕するため比，

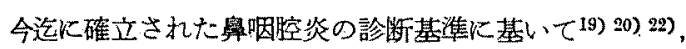
炎症性变化を観察し，それと共に消長する細菌丵を観察 した.

特に塗抹像に括ける穓察の目的は，鼻咽腔に棲息する 細菌のなまの状態をそのまま載物硝子に移し換えて観察 し，逆沉ありのままの炎症性環境を推定しょうとしたの である. その結果形態的観察による菌種, 菌量の変化を 菌叢曲楾 ${ }^{24)}$ と名づけて，全应例を 観察したところ，6 型の型に分類できたのである. 又これが，炎症の消長即 ち触痛，後鼻漏，上皮涂抹像，等之上く一致し，多少の 時相の盖はあつたが，鼻咽腔炎の経過を示するのとい充 る事がかからたのである。

そこでこの結果の如く，鼻咽腔炎の炎症性変化につれ て, 細菌叢が变化する様子を急性鼻咽院资に括ける細菌 の捿息環境の観点から考察すると，一般に炎症宩では初 期は $\mathrm{pH}$ がフルカりで，炎症巣に打ける解糖作用の結

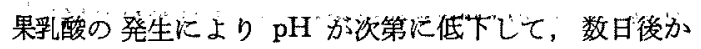

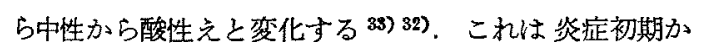
ら急速に細菌発育に最適の $\mathrm{pH}$ となつて菌の增殖が始 り，数日後から漸時减少して行く過程とよく一致してい ว.

一方臨床所見である触痛であるが，炎症巣ではヒスタ ミン様物質と共に組織液の酸性化と $\mathrm{K}+$ の增加により痛 覚が增強されるのであり ${ }^{32}$ ，特に酸性化が数日後であ るとすると，榆查結果の触痛增強の時期と一致してい ๖.

更に後鼻漏の出現期に菌量も最高となる事は，炎症巣 で侮害された资症性細胞や，白血球が autolyse を起し， 虫白分解産物が菌の栄差物となる時期にも一致している 事とも関俰があると思 5.

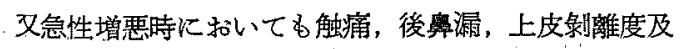

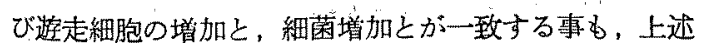
の理由と深い関係があると推定される. 即ち急性增悪の
炎症環境が細菌增殖に好都合な条件を作り，そのために 細菌は增殖すると考えられる。

一方治療に上り消炎之共に菌量の減少を見るのは，炎 症環璄が次第に菌棲息に不利になる一方，治療菜となつ

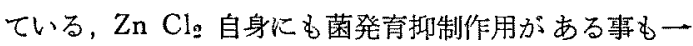
役實つていると思う。

又この治療に抵抗し，菌蹱の固定化するV型の菌種 は, 生活可能域の $\mathrm{pH}$ が菌種で最も広い非溶血ブ菌が 大部分である事は，炎症性環境儿括いては，非溶血性ブ ドウ球菌が最す生活力はあるが炎症沈直接関係のな い事を物語つている。

以上の如く，番咽腔炎の経過と菌叢曲線との観点から は，鼻咽腔炎では炎症がまづ先に起り，繶いて細菌の增 殖があると考光られるのである，要するに菌叢曲線は炎 症性变化汇指ける附随現象として菌量の变化示示可の であるが，同時に又，時相の差慬かであるので，奥咽 腔炎の経過を示すといら事もできるのである.

\section{2、培堆成績に関する検討}

正常者では塗抹像, 培養共に（一）であつたり例充認 められても塗抹像で菌量が函めて僅かである事と，発育 菌も，生活条件の広い非溶血性ブドウ球菌が少数認めら

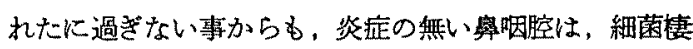
息には不適な場と考えられる。しかし一旦炎庭が起ると 細菌発育に好都合な場所となるのである。例之ば

F. Neuberger は，Deviatomie の前後に怙ける細菌 相の変化を観察したが，それによると，手術により，組

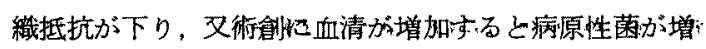
加する. 術創が治り，組織抵抗もできて，全身免疫もで きると病原性菌が減少するという。

このよらに細菌は炎症環境に敏感に反応し消長を示す ものである.

そこで今回の培養成績に敊かる菌種の検討をしてみる と,

病原性球菌とされている溶血性ブ菌及び肺炎双球菌，

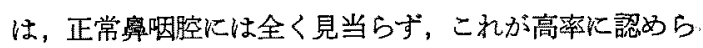
れた症例では，鼻咽腔炎も著しいるのが多かつた，殊に 溶血性ブ菌に関しては, 症例の如く, 同一菌種が，炎症 增悪時に增加し, 他の菌種の增加が認められなかった事 実は，次の事項を裏書きしていると思う。

即ち細菌叢に関する生態学の数党るところによれば31〉

i) 粘膜面で，ある菌種が住みつくと，他の菌種の侵 入があつても住みつきができない，小林なこれを粘膜と 細菌との有機化といつている. 
ii）俱位菌種は，その生活場所に最る適した種であり， 密度や数も最大で，增殖にも最も安定している。

次に塵埃㻴境にある人と溶血性ブ菌の問題であるが，

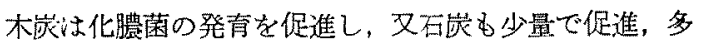
量で抑制作用あり30) と，雨者の関係は複雑だが，少く

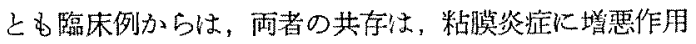
を及ぼす青を想像させる。

次に集落の型と菌丵曲線の検討であるが，鼻㸶腔の組 織及び体液を培地と考党ると，人工培地と内容的に塂る のみならず 时々刻々その化学的緝成が変動しているか

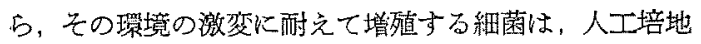
と同捄の細菌と根本的に巽る事は明らかである ${ }^{33)}$. そ こで登抹像の観察の如さ生のままの観察でなく，人工培 地に移し換えられた状態に打ける菌種の比較観察に止る わけたが，血液寒天培地上の集落は in vitro 上はいえ， 二応その時期の粘膜の炎症環境と親和性を有する囷種の 状態を示するの之考克られるから，その集落の型之，夙

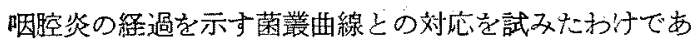
乃.

即ら2〜3種の菌が発育する場合は，非病原性球菌を

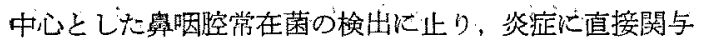
すると思われる菌種はなく，與咽腔炎の経過も良い。

一方純培㓌状態儿発育す西場合は, 特心病原性球菌の 埸合，ての菌種か次症性增墨に関与してい尚と思われる。 殊に染抹像で他の菌種が多く認められる場合は，これら の菌種を抑えて発育活動して炎症に閶係している年を想 潒させる。文一方このような症例で臨床像及び上皮塗抹 像の炎症性梦化が特儿著しい事から日，この菌が粘膜に

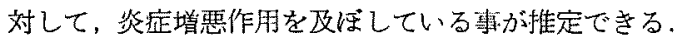

多種混合型集落の場合が，慢性経過に多いのは，粘膜

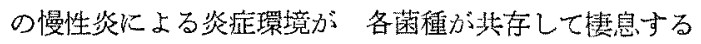
状態を満足させていると考えられる。

\section{3. 動物実験の検討}

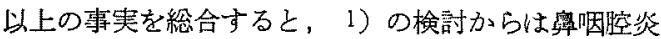
では，炎症がまつ先で，只の附随現象として細菌增殖が 考之られるが，一方2)の培養成績の検討から，溶血性 ブ菌は，次症性变化のある粘膜に更に堌悪作用を及ほすす 事が推定された。そこで

病原性ブドウ球菌 209p を家鬼煘㸶腔粘膜に注入実験 したところ，整度ではあるが，炎症性変化を起し，しか 子菌の增殖発育之, 炎症性変化の消㩖とがよく一致して いだ.

正常鼻咽腔の維持のためには，常死紲菌叢の影響及び
跕膜の菌に効する抵抗性といつたるのが，かなり大きな 役割を演じている事方予想されて特り，たと文病原性球 菌でも粘膜上からの刺激作用芯けでは，軽度の一過性の 変化しか起し得えなかつた擘は当然の事と思う。

しかしながら䵇埃の代表として炭汾が加わると，粘膜 の㷋症性变化を晴強し，細菌の活動の基礎を造ると思わ れる。

これはあく迄も家乘粤咽腔による炎症性反心の实鼠結 果で，これ直ちに人間の臨床と結びつける事は他険だ が，臨床例と台せて考慮すれば，充分参考心なり得ると 思亏。

\section{7. 結 論}

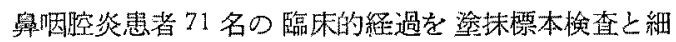
菌培善を行いながら钼察し, 細菌叢の変化を示す菌叢曲

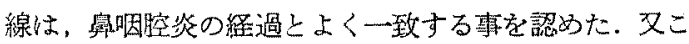
の菌哣曲線之，血液寒天培地上に現われた集落つ型との 間に”鼻咽腔炎の経過の点で密接な関係がある李を認め た，更に急性增悪反琵型や，慢性型に関係する現象とし て，菌量の增加があり，特に純培善状態に検出された菌

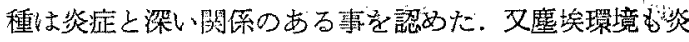

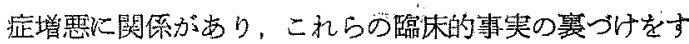

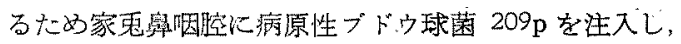

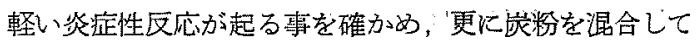
注入すると更に炎症が強さる事定認め，溶血性ブドウ球

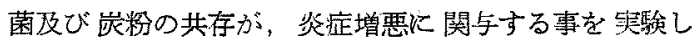
た.

\section{答 考文 献}

1) L.Goldmann J.L.: Bacteriologic and clinical interpretation of the flora of the nose and nasopharynx in children. J. Pediat. 44: 299, 1954. 2) L.Goldmann J. L.: Bacteriologic aid in rhinologic diagnosis and trcatment. Improved criteria. Laryngoscope 62: 406, 1952. 3) L.Goldmannd J.L.. Bacteriology and clinical interpretation of the flora of the nose and nasopharynx in adult. Ann. Ato. 59, 156, 1950. 4) Theowbald, W.H.: Associated symptomatology of the epipharynx. Ann. OR.L. 57, 678,1948 . 5) Bakteriologie der Nase: Handbuch der speziellen pathologischen Anatomie V. Histologie. 6) Marian P.: Human ciliated epithelial cells in nasal secretions Morphologic and histochemical aspects. Ann. 73,474, 1964 . 7) J.Thomas Rulon.: Clinico-Histological study of chronic pha- 


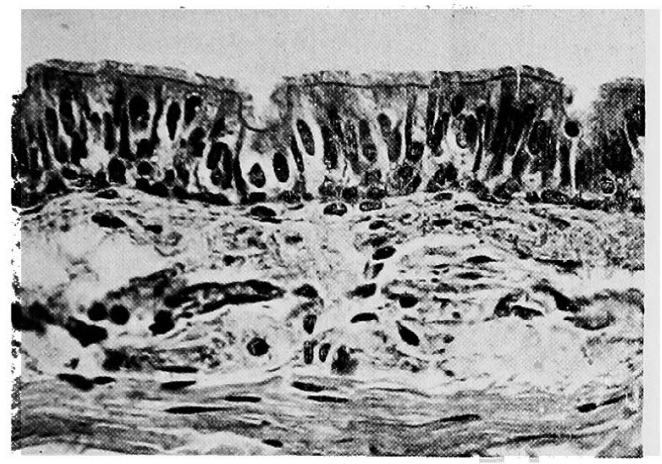

I 正常像

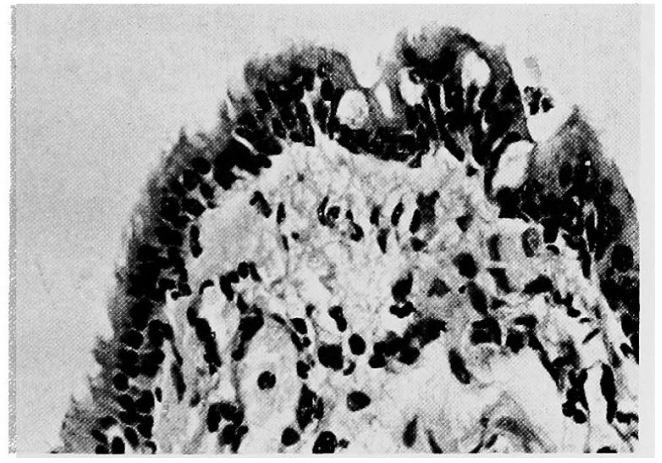

III菌液注入 6 時間後

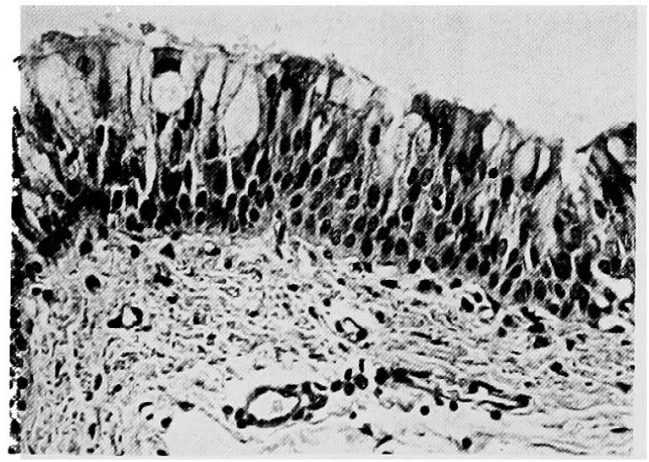

V 菌液注入 24 時間後

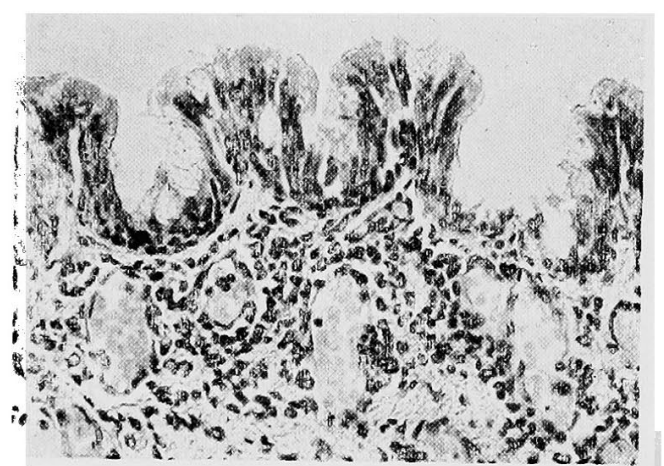

II 菌液注入 3 時間後

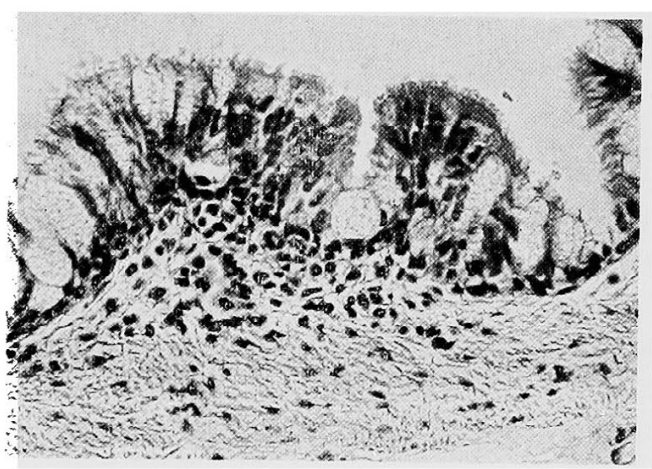

IV 菌液㳕入12特間後

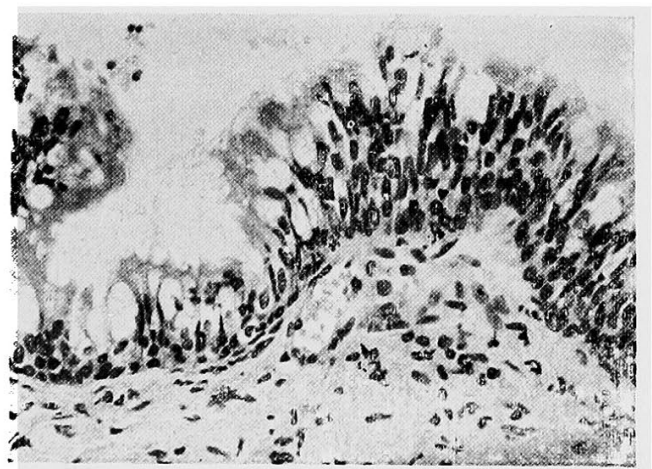

V菌液十炭粉注入 3 時間後 


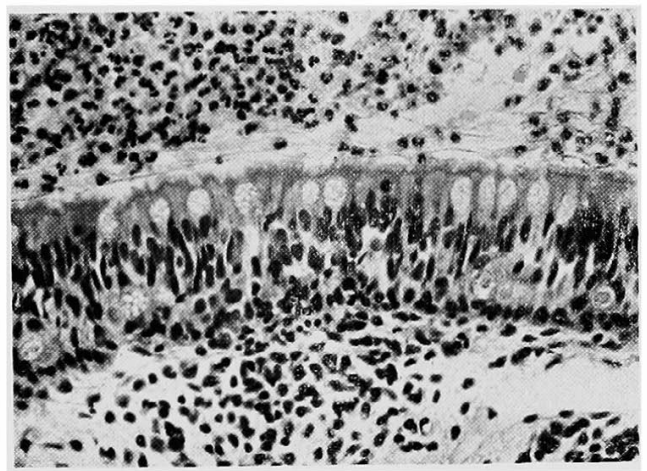

VII 染液+岑粉注入 6 脚間後

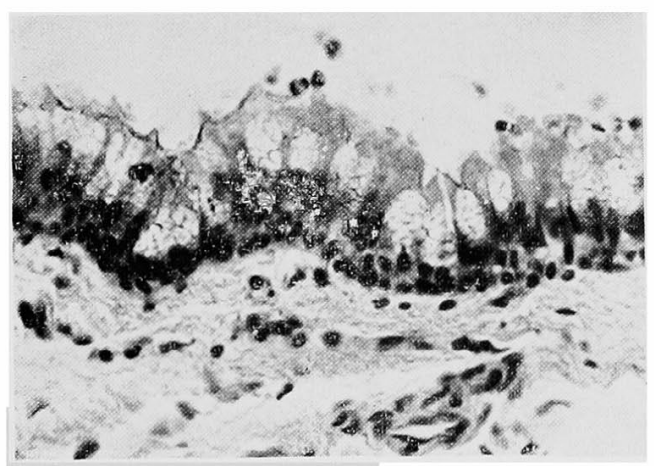

IX 菌液+炭粉注: 24 情間後

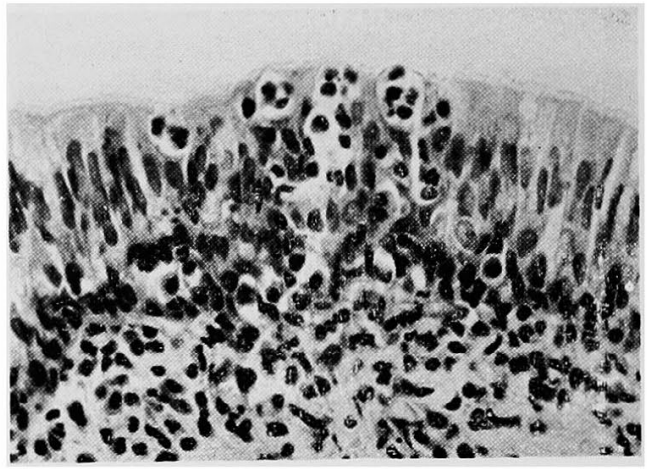

VIII菌液十孷粉 12 時間後

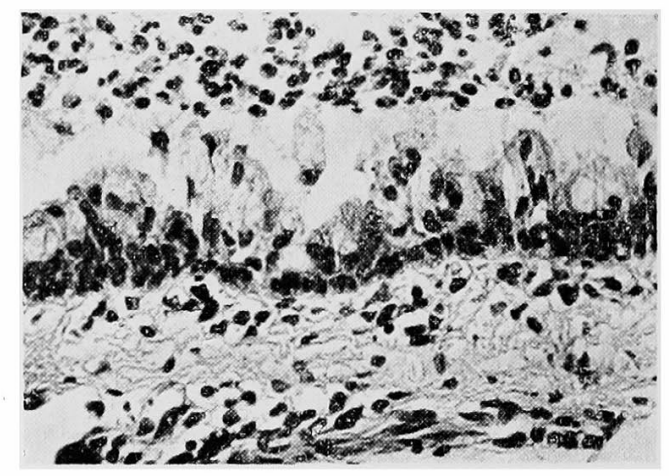

X菌液十炭粉6 回速日泎入12時間後

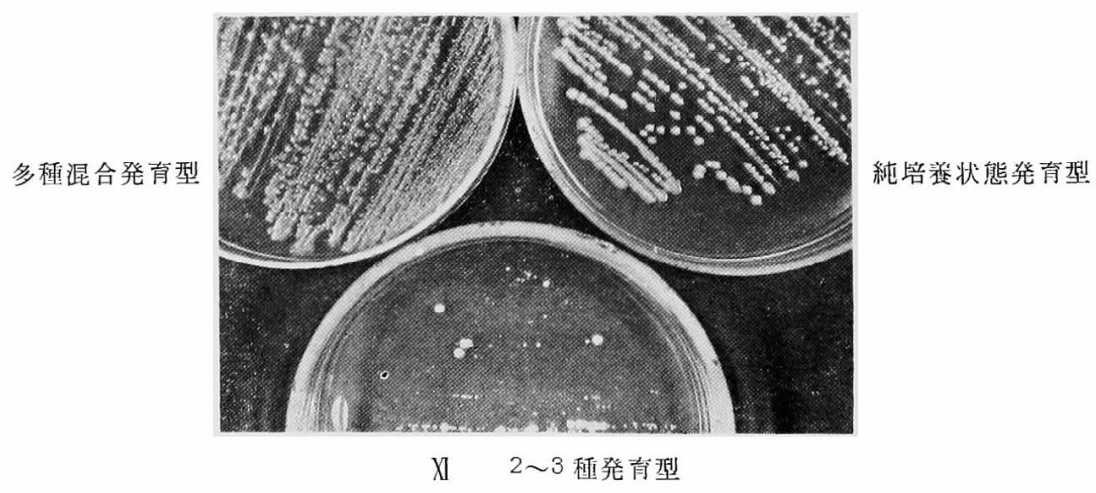


yyngeal symptoms. An.n Oto. 73, 501, 1964.

R.E. Rewell.: Pathology of the upper respiratory tract. 1963 9) Robert C.: Antimicrobial Factors of normal Tissues and Fluids. Bact. Reviews. 21, 273, 1957. 10) Rosebury: Microorganisms Indigenous to Man. Mc Graw-Hill, 11) Gennaro J.: Possible source of secondary invading staphylococci in mice exposed to acute cold. J. Bact. 85. 2. 345, 1963.

Rontree; Nasal carriage of staphyloccus by various domestic and laboratory animals. J. Bact. 72, 319, 1956. 13) W.A. Sodeman.: Pathologic Physiology Mechanismus of Disease. 14) J.G. Hisch.: Antimicrobial Factors in Tissues and Phagocytic cells, Bact. Rev. 24, 133, 1960. 15) Burian, $\dot{K}$. Ü Über die Restitutionsfahigkeit des Flimmerepithels der nase nach totaler Zerstörung des Epithels. zeitschrift L-R-O 39, 387, 1960 . 16) Probst, R.: Über cytologische Diagnostik in der Oto-Roino-Laryngologie, Arch. O-N-K hk. 169 169, 1953, 17) 垭口申

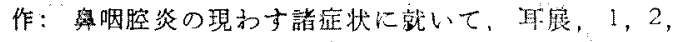

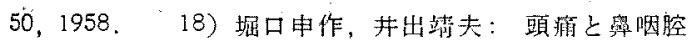
炎，日菆奥，65，12，1360，1962。19）村上于:

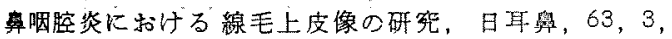

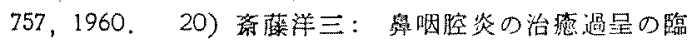
床的並びに㔀睢細咆学的研究，日耳鼻，66，6，814，

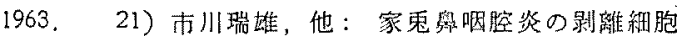

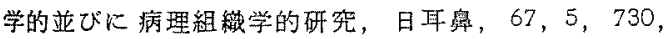

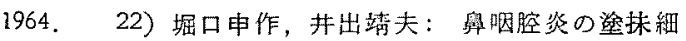

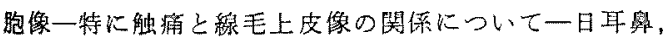
$67,2 ， 153 ， 1964$ 23) 谷川譫：篻染色標本加5見 た鼻咽腔細菌像，日耳蛔，66，10，1240，1963。24)

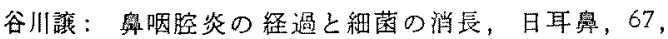
$4,613 ， 1964$ 25) 渡辺景子：咽頭粘膜における細

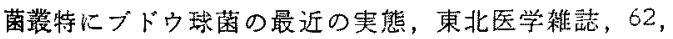

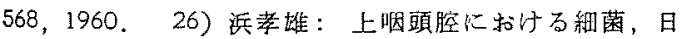
耳鼻, 56, 3, 169, 1953。27) 试田政英, 他: 㧢頭 扁桃の紐菌, 日耳鼻，57，10，1017，1954。28）林泗

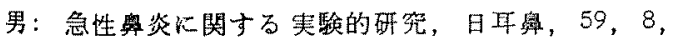
1409，1956。29）瀨川良二：頸䡃脈結絷の學腔に及 ぼす影箁に就いての実験的研究，市立札幌病院雑誌， 17，3，1957，30）松村威：石炭の化膿菌の発青に及

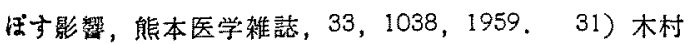

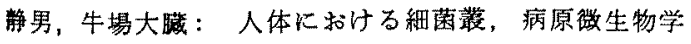

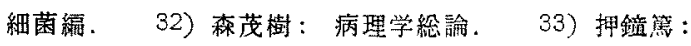

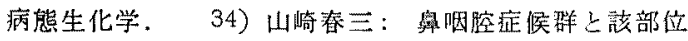
に関子る病理学的研究，日耳礐，67，1663，1964. 35)

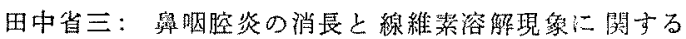
研癷，日耳畭，68，5，675，1965。

\section{付图説 明}

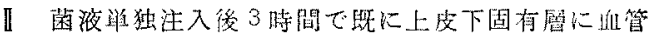

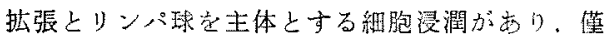
かながら好中球を混している。

四6時間後では，上皮間の結合がやや疎になり，少 数ながら好中球の上皮内浸潤をるる、上病固有㬝 は高度の漿液漫潤をきたしている。

VI12時間後では，上皮細胞間の水腫及び括中理浸潤 は消退し，固有層の炎症性变化整減してい弓。

V24洔間以後は，上皮層は多少上皮細胞の配列が乱 れているが，㷋症性变化は殆んと消泹し，固有層 に少数のリンパ球及び好中球の浸潤が残つている に過きない。

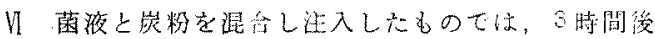
で上皮間に少数ながら細胞浸洞があり，固有層か

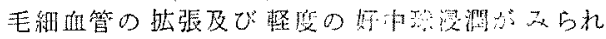
万.

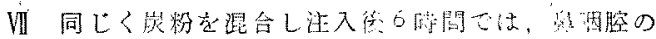

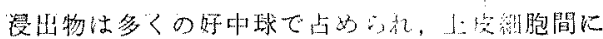

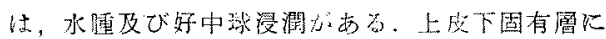

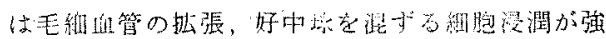
い。

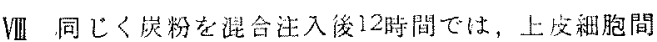

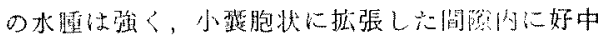

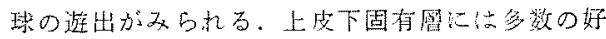
中球が瀑润してい各。

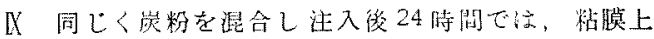

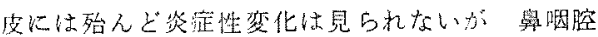

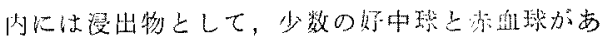

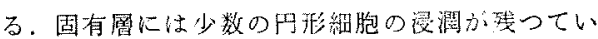
当.

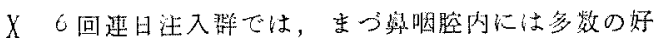

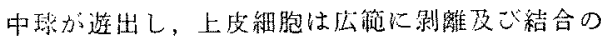
弛䜌をきたしている。文上皮下には桨定性水腫が

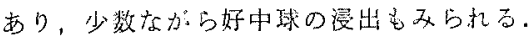

雅を終るに当り，御指導御校阔を睗つた琹師 堀口白作教授，細菌学教室清水文房教授及ざ難

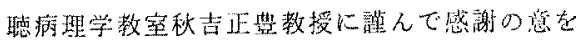
表します。

(原街到福 $=$ 昭和 $40,0,16$ 日) 